Article

\title{
Augmented Reality and Valorizing the Mesozoic Geological Heritage (Burgos, Spain)
}

\author{
Antonio Martínez-Graña *®i], José Ángel González-Delgado, Celia Ramos®® and \\ Juan Carlos Gonzalo \\ Department of Geology, Science Faculty, Plaza de los Caídos s/n, 37008 Salamanca, Spain; \\ angel@usal.es (J.Á.G.-D.); c_ramos@usal.es (C.R.); jcgonzalo@usal.es (J.C.G.) \\ * Correspondence: amgranna@usal.es; Tel.: +34-923-294-546
}

Received: 21 November 2018; Accepted: 3 December 2018; Published: 5 December 2018

check for updates

\begin{abstract}
This article presents the application of augmented reality through the use of devices in the valorisation of the geological heritage of six known geosites of the Jurassic or Cretaceous age, located in the South-East (SE) of the province of Burgos (Castilla y León, Spain). Using augmented reality techniques, geomatic resources have been developed that allow real-time interaction with different thematic layers (e.g., cartography, digital terrain model, etc.). Using these techniques, this paper proposes a virtual route in Google Earth and a Field Trip Guide with a detailed description of each site and suggested activities for educational use and one free geoapp. These geosites comprise three zones with deposits of dinosaur ichnites and three other sectors with marine fossils (Jurassic limestones), fossil trees, or singular karstic landscapes. The globalization of geodatabases allows the intelligent use of geo-resources and their use for tourism, didactic and scientific purposes.
\end{abstract}

Keywords: augmented reality; digital and virtual geoheritage; geological heritage; palaeontology; geomorphology; 3D Georoute; Burgos-Spain

\section{Introduction}

The study of Earth sciences includes different disciplines related to geology, such as geomorphology, palaeontology, tectonics and stratigraphy, as well as the analysis and observation of geological structures, materials and geodynamic processes that give rise to sedimentary and fossil forms and structures.

In recent decades, particular effort has been made to preserve the natural environment, classifying and paying special attention to endangered plant and animal species. At the same time, rural tourism has been developed, which has increased knowledge of natural areas and made the population aware of its pollution and deterioration. For this reason, most countries are expanding an increasingly specific legislation to protect this natural inheritance and promote geoconservation.

The analysis of geological heritage complements in a very effective way the didactic approach from itineraries and field practices where the participants are immersed in the geological heritage of the area in which they live [1-3]. It is important that fieldwork is not seen as a secondary activity but as a fundamental part of the curriculum. In addition, the attitudes of fieldwork and the concepts of geology help to understand and interpret the natural environment. Promoting knowledge of this field is fundamental to understanding concepts of geological structures, enhancing the didactic activities of research in class or extracurricular activities (fieldwork) and promoting the observation capacity and discussion of anthropic problems in the natural world [4-9].

This work presents a route through the province of Burgos (Spain), which includes six stops at geological sites of the Jurassic and Cretaceous ages, where the different geosites are valued and analysed and a field notebook with information on the scientific, didactic, and/or touristic interest of 
each zone is elaborated, including geo-resources and interactive geomatic applications [10-15]. The use of augmented reality with free platforms such as Google Earth enables the visualization of the route and facilitates the understanding of geological spatial distribution, including interpretations and photographs.

The quantitative methodologies of valuation of the geological heritage that calculate the scientific, educational and touristic value of the geosites do not have a broad international consensus, there being discussions about the parameters, weights and weighting coefficients [16-19].

The main objective is to value the geological and natural heritage through a procedure that allows participants (tourists, students, etc.) to participate in an active and very simple way in learning theoretical concepts of Earth Sciences [20-23]. The aim is to highlight the value of the geological inheritance of a natural area through the creation of a virtual itinerary by implementing augmented reality and evaluating geosites according to their scientific, didactic and tourist-cultural interest. For this, geomatics resources are developed so that participants can interact in "real time" with different thematic layers, virtual reality developed with Google Earth, flight simulators, guides and field notebook with activities, besides facilitating the use of a geoapp created for smartphones, generating learning based on the use of new technologies of great social acceptance [24-27].

\section{Materials and Methods}

\subsection{Study Area and Geological Context}

The itinerary takes place in the southeast of the province of Burgos (Castilla y León, Spain) (Figure 1) with the idea that potential participants can have the opportunity to discover the geological heritage of the place that will serve as a base for other heritage: biological, ecological and cultural.

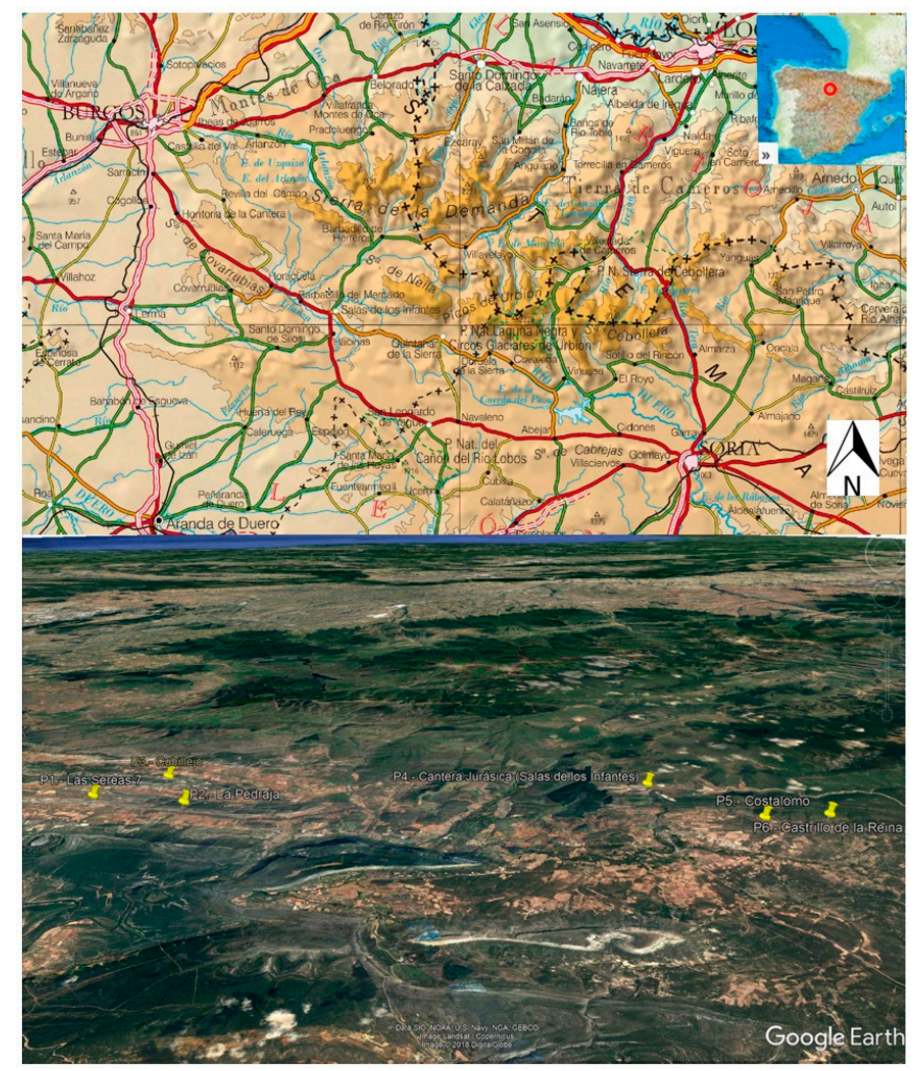

Figure 1. Location of the study area on the topographic map (up) scale 1/500,000 and location of the geosites on Google Earth (down). 
The analysis and distribution of the different geological materials in this area reveal its evolution over time based on paleoenvironmental and paleogeographic information. The oldest materials are dated from the Upper Jurassic, corresponding to sandy limestones of marine origin (about 166.1-168.3 million years (m.y.) old) and the most modern correspond to limestones and continental marls of the Upper Cretaceous (about 93.9-100.5 m.y. old). The geosites of the itinerary date from the same period, which enables the creation of a global vision of the evolution of life in the study area (Figure 2). We found marine evidence of the Upper Jurassic as bivalve shells in sandy limestones but only a few kilometres from the area we have conglomerates and limestones from the Lower Cretaceous with dinosaur footprints and evidence of the lacustrine environment in which they lived. The most modern evidence included in the itinerary corresponds to the remains of a podocarpaceous tree several meters high typical of a terrestrial forest ecosystem dating from the Upper Cretaceous.

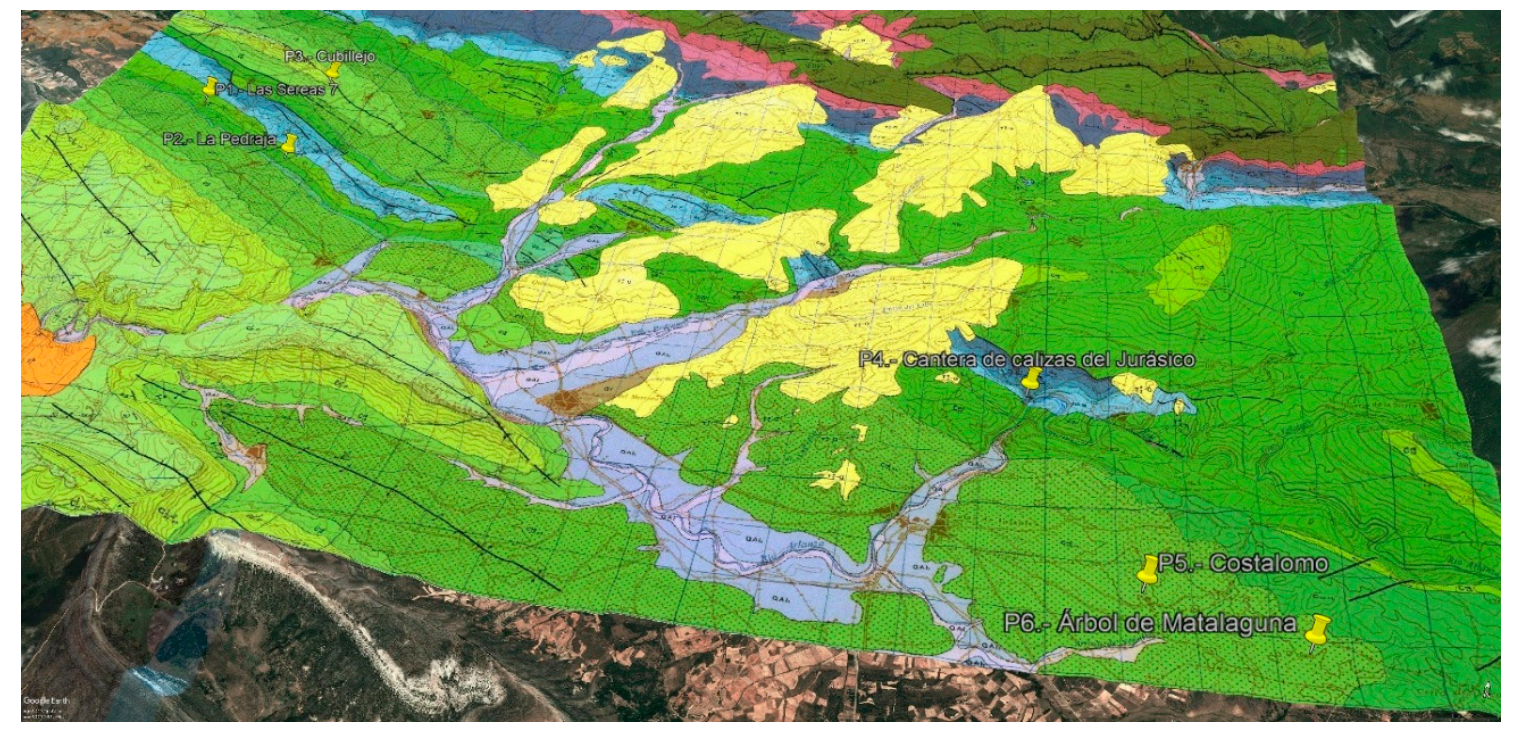

Figure 2. Digital globe with superposition of the geosites on a 3D geological map where it is observed with light green colour the alternation of limestones and marls; Green: conglomerates, Dark green: limestones; light blue: alternating sandy limestones.

Thanks to the terrestrial dynamics, the study area has evolved along with the living organisms that inhabited it. As a result of the Alpine orogeny, the geomorphology of the area was formed, marked by limestone banks that have been eroded by rivers and streams. To identify the geosites, several field trips and bibliographic analyses were carried out (scientific articles and theses), generating a description and synthesis in sheets for each geosite, including their coordinates and a geological description of interest, photographs, interpretive schemes and so forth.

\subsection{Inventory and Valuation of Geosites}

First, we proceed to identify, classify and evaluate the different geosites that are included in the geological itinerary. Six stops are identified and the valuation is based on assigning between 0 and 4 points to a total of 18 parameters (Table 1) related to the geosite [24], namely: representativeness, character of type locality, scientific importance, conservation, observation conditions, rarity, geological diversity, educational use, infrastructures in the area, population density, accessibility, size, association with other eco-cultural elements, beauty, informative content/use, potentiality to carry out informative activities, proximity to recreational areas and socioeconomic environment. 
Table 1. Parameters analysed in each geosite.

\begin{tabular}{|c|c|}
\hline Parameters & Intrinsic Value \\
\hline \multicolumn{2}{|l|}{ Representativeness (quality of location to adequately illustrate the features of the domain) } \\
\hline Little useful as a model to represent, even partially, a trait or process & 0 \\
\hline Useful as a model to partially represent a trait or process & 1 \\
\hline Useful as a model to represent a trait or process & 2 \\
\hline Best-known example and geological domain level considered to represent a trait or process & 4 \\
\hline Character type locality or benchmark (quality of place as a stratigraphic, paleontological and mineralogical reference) & Intrinsic value \\
\hline Does not meet, by default, with these three following premises & 0 \\
\hline Useful as a model to partially represent a trait or process & 1 \\
\hline Useful as a model to represent a trait or process & 2 \\
\hline Best-known example and geological domain level considered to represent a trait or process & 4 \\
\hline Level of scientific knowledge of the location (geological relevance and scientific interest in publications and studies) & Intrinsic value \\
\hline There are no published articles or doctoral theses on the place & 0 \\
\hline Published studies and/or doctoral thesis about the location & 1 \\
\hline $\begin{array}{l}\text { Focus of research by scientific teams and the subject of doctoral theses and published papers that have been referenced in national } \\
\text { scientific journals }\end{array}$ & 2 \\
\hline Focus of research by scientific teams and the subject of doctoral theses and published papers in international journals & 4 \\
\hline State of conservation (existence of physical deterioration of the trait) & Intrinsic value \\
\hline The place has significant deterioration or is destroyed & 0 \\
\hline With impairments that prevent appreciation of some features of interest & 1 \\
\hline Some defects, which do not decisively affect its value or interest & 2 \\
\hline The geosite is well-preserved & 4 \\
\hline Viewing conditions (offered by the environment to observe the trait). & Intrinsic value \\
\hline With elements that strongly mask the characteristics of interest & 0 \\
\hline Contain elements that do not enable appreciation of some features of interest for the geosite & 1 \\
\hline Contain elements that do not enable complete observation of the geosite, despite the difficulty & 2 \\
\hline Perfectly and easily observable in its entirety & 4 \\
\hline Rarity (shortage of similar traits as described) & Intrinsic value \\
\hline There are quite a few similar places in the region & 0 \\
\hline One of the few known examples at the regional level & 1 \\
\hline Only example known at the regional level & 2 \\
\hline Only example known at the national level (or international level) & 4 \\
\hline Geological diversity (the existence of various types of geological interest in the same location) & Intrinsic value \\
\hline The geosite only presents the main interest rate & 0 \\
\hline The geosite has other interests in addition to the primary interest, which are not relevant & 1 \\
\hline The geosite has two types of interests in addition to the primary interest, or only one relevant interest & 2 \\
\hline The geosite has three or more types of interests in addition to the primary interest but only two interests are relevant & 4 \\
\hline Educational content/educational use identified & Intrinsic value and use \\
\hline Does not meet, by default, with the following three premises & 0 \\
\hline Illustrates university content of curricula & 1 \\
\hline Illustrates curricula at all levels of the educational system & 2 \\
\hline Commonly used in educational activities at all levels of the educational system & 4 \\
\hline Logistics infrastructure (Existence of lodging and restaurants) & Use value \\
\hline Does not meet, by default, with the following three premises & 0 \\
\hline Accommodations for groups with 20 people within $25 \mathrm{~km}$ & 1 \\
\hline Accommodations for groups with 40 people within $25 \mathrm{~km}$ & 2 \\
\hline Accommodations for groups of 40 within $5 \mathrm{~km}$ & 4 \\
\hline $\begin{array}{l}\text { Population density (demand immediate potential) (Linked to the potential number of visits and the increased potential for } \\
\text { vandalism) }\end{array}$ & $\begin{array}{l}\text { Use value and } \\
\text { protection }\end{array}$ \\
\hline Less than 200,000 inhabitants within $50 \mathrm{~km}$ & 1 \\
\hline Between 200,000 and $1,000,000$ inhabitants within $50 \mathrm{~km}$ & 2 \\
\hline More than 1,000,000 inhabitants within $50 \mathrm{~km}$ & 4 \\
\hline Accessibility (Linked to easier access and a greater potential for vandalism) & $\begin{array}{l}\text { Use value and } \\
\text { protection }\end{array}$ \\
\hline $\begin{array}{l}\text { Does not comply, by default, with the following three premises (road asphalted with no possibility of parking, path or path, track } \\
\text { TT, boat, etc.) }\end{array}$ & 0 \\
\hline Direct access by dirt road but passable & 1 \\
\hline Direct access by paved road with parking for cars & 2 \\
\hline Direct access by paved road with parking for coach buses & 4 \\
\hline Size of the geosite & $\begin{array}{l}\text { Use value and } \\
\text { protection }\end{array}$ \\
\hline Metric traits (vulnerable by visits, such as speleothems, etc.) & 0 \\
\hline Not vulnerable as visits but more sensitive to human activities and decametric aggressive traits & 1 \\
\hline Hectometric features that may experience deterioration by human activities & 2 \\
\hline Kilometric traits that are not damaged by human activities & 4 \\
\hline Association with other nature/cultural elements. The site also does not contain other elements of geological interest & Use value \\
\hline There are no elements of natural or cultural heritage within a radius of $5 \mathrm{~km}$ & 0 \\
\hline Presence of a single element of natural or cultural heritage within $5 \mathrm{~km}$ & 1 \\
\hline Presence of various elements of natural and cultural heritage within $5 \mathrm{~km}$ & 2 \\
\hline Presence of various elements of natural and cultural heritage within $5 \mathrm{~km}$ & 4 \\
\hline Visual beauty or spectacular trait or quality & Intrinsic value \\
\hline Does not meet, by default, with the following three premises & 0 \\
\hline Used only in the local tourist iconography & 1 \\
\hline Used occasionally in the tourist iconography at the national or international level & 2 \\
\hline Typically used in the tourist iconography at the national or international level & 4 \\
\hline Informative content/use detected. The feature is easily identifiable or already used for this purpose & Intrinsic value and use \\
\hline Does not meet, by default, with the following three premises & 0 \\
\hline Demonstrates clear and expressive manner for groups of certain cultural levels & 1 \\
\hline Demonstrates clear and expressive collective cultural level any way about the importance or usefulness of geology & 2 \\
\hline Commonly used for outreach activities & 4 \\
\hline $\begin{array}{l}\text { Potential for tourism and recreational activities. The location satisfies the conditions for conducting activities or is already } \\
\text { used for this purpose }\end{array}$ & Intrinsic value and use \\
\hline No tourist possibilities or recreational activities & 0 \\
\hline You can make develop one of these activities & 1 \\
\hline You can perform these activities & 2 \\
\hline These activities are usually organised & 4 \\
\hline
\end{tabular}


Table 1. Cont.

\begin{tabular}{lc}
\hline \multicolumn{1}{c}{ Parameters } & Intrinsic Value \\
\hline Proximity to recreational areas (demand immediate potential) Linked to the potential number of visits and the increased potential \\
for vandalism
\end{tabular}

The data obtained for each parameter is multiplied by different weighting coefficients depending on the type of value (scientific, didactic, or tourist) that is being calculated (Table 2). For the scientific evaluation, a maximum weight of 30 points is assigned to representativeness, followed by a maximum weight of 15 points for the degree of scientific knowledge of the place and the rarity, and, finally, the character of the locality type, conservation status, observation conditions and geological diversity each have a maximum weight of 10 points. For the didactic evaluation, a maximum weight of 20 points is assigned to the content or didactic use detectable, followed by of 15 points for the logistical infrastructure, 10 points for the accessibility and geological diversity and 5 points for representativeness, the degree of the type locality, the state of conservation, among others. For the tourist valuation, a maximum weight of 20 points is assigned to spectacularity or beauty, followed by a maximum of 15 points for the size of the GIP and the content or informative use, with 10 points for the accessibility and a maximum value of 5 points for observation conditions, logistics infrastructure and population density, among others.

The geosites that have been valued are the Deposit of Las Sereas 7 (P1), La Pedraja (P2), Cubillejo (P3), Quarry of Jurassic Limestones (P4), Costalomo (P5) and Fossil tree of Matalaguna (P6) (Figure 1).

Table 2. Weights for each parameter as a function of interest.

\begin{tabular}{lccc}
\hline \multicolumn{1}{c}{ Parameter } & Scientific Interest & Educational Interest & $\begin{array}{c}\text { Tourist/Recreational } \\
\text { Interest }\end{array}$ \\
\hline Representativeness & 30 & 5 & - \\
Character type locality & 10 & 5 & - \\
Degree of scientific knowledge of the location & 15 & - & - \\
State of conservation & 10 & 5 & 5 \\
Viewing conditions & 10 & 5 & - \\
Rarity & 15 & 5 & - \\
Geological diversity & 10 & 20 & 5 \\
Learning objectives/educational use & - & 15 & 5 \\
Logistics infrastructure & - & 5 & 10 \\
Population density & - & 10 & 5 \\
Accessibility & - & 5 & 20 \\
Intrinsic fragility (geosite size) & - & 5 & 15 \\
Association with elements natural and/or cultural & - & - & 5 \\
Beauty or spectacularity & - & - & 5 \\
Informative content/use & - & - & 10 \\
Potential for tourism/recreation activities & - & $\mathbf{1 0 0}$ & $\mathbf{1 0 0}$ \\
Proximity to recreational areas & $\mathbf{1 0 0}$ & & \\
Socioeconomic environment & Total & & \\
\end{tabular}

Once identified, catalogued and valued, the six geosites that constitute the itinerary stops are georeferenced in the free Google Earth application in " $\mathrm{kml}$ " format. The application allows us to change the icon and assign different colours depending on the type of heritage interest, for example, if we want to combine a geological route with a gastronomic one (Figure 3A). Next, the geological map on the 3D virtual globe is superimposed to relate the lithology of each place of interest. To facilitate the augmented reality, representative images, information sheets with their description and specific cartography, for example, the geomorphological geosite and schemes and interpretations of the geosites 
observable in the real terrain are geolocated at each stop, while the mobile application analyses their interpretation (Figure 3B,D). In this way, augmented reality enables a better understanding and vision of the contents on the itinerary that will guide us through the different geosites in digital flight. This spatial journey along the geography and on the orthophoto that our mobile device loads thanks to the use of integrated GPS allows the participant to interact with the geological, natural and even cultural heritage that is presented on the route, since this itinerary allows you to load more Google Earth's own layers, such as interest places, roads, urban areas, all over the orthophoto projected on the 3D globe. The route is decided by the participant, who chooses and analyses the geosite's subscription by clicking on the "Kml," the text appears on the virtual balloon and under the description you can click "From here" and then choose the geosite where you want to go by clicking on "To here" (Figure 3B). With this, the mobile device calculates and draws the route based on Google Earth's geodatabase, tracing the shortest route over the orthophoto or over the thematic cartography that has been superimposed. To these cartographies you can apply a grade of transparency that allows you to observe the orthophoto (Figure 3C,D).
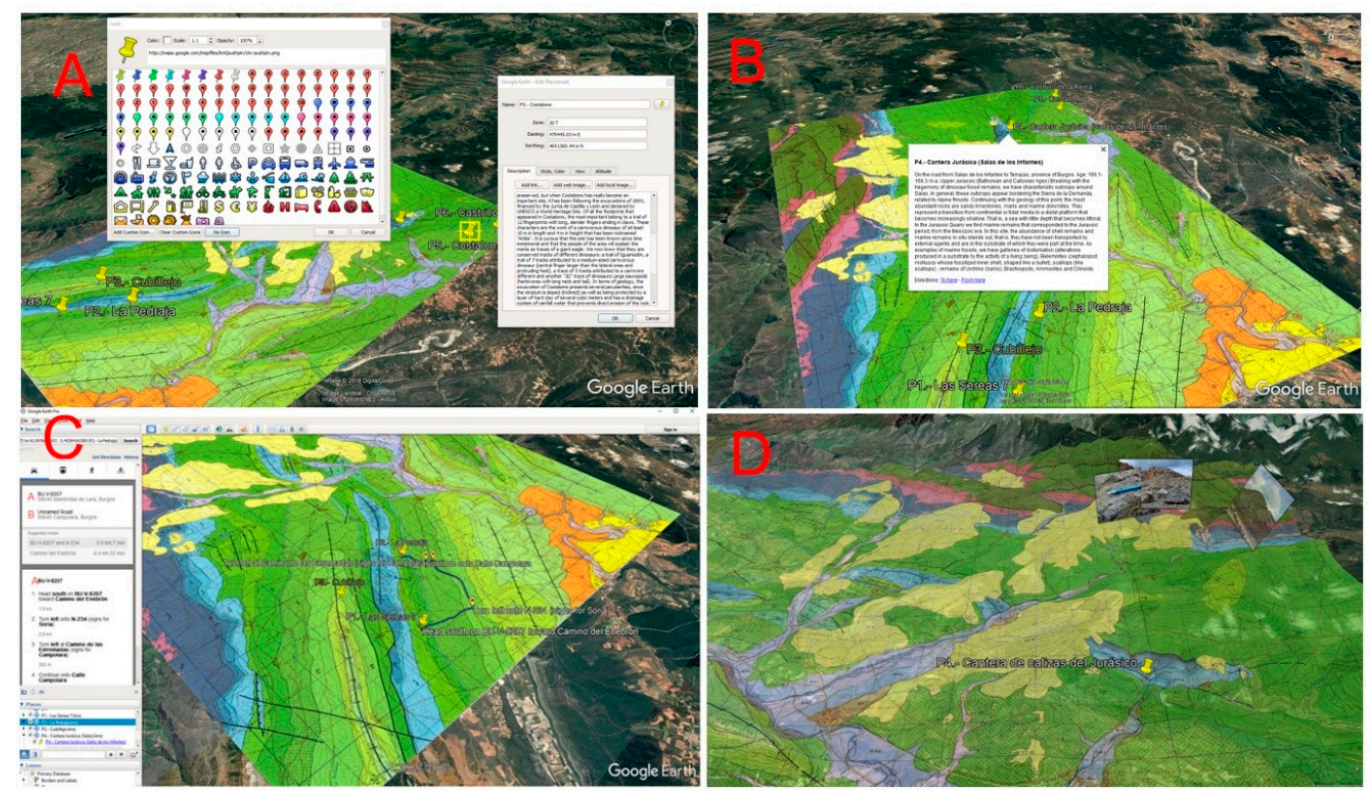

Figure 3. (A) Screenshot of placemarks and description of geosites. (B) Descriptive of the geosite 4 to the flight when pressing on the placemark of the pin. (C) Automatic generation of the route (blue line) between stop 1 and stop 2 with indication on the transparent cartography of the route. (D) Capture of the augmented reality resulting from loading different images and interpretive schemes of some stops that appear when approaching the geosites on the 3D virtual digital globe.

The operation of Google Earth allows interaction with the mobile device (smartphone, tablet, iPod) by analysing the difficulty of the journey by obtaining the route information with an elevation profile (Figure 4A), which is obtained from the option "show elevation profile" in the table of content on the left side of the window. In addition, the Google Earth platform can integrate the Street View application (Figure 4B), a Google Maps application, which allows profiles to be virtually analysed from the road by car, bus, or walking, taking advantage of GPS as a navigator indicating if the sound volume of the device activates the route by turning directions (right/left) and the name of the streets and roads by audio and visually on the map with the geolocated geosites, providing the route, the distance and the estimated time (Figure 3C).

This itinerary, implementing augmented reality, can be recorded, saved and played with Google Earth. It also allows us to make a flight or virtual route on the geological map, where the user interacts with the geological and natural heritage as if it were a game, being able to choose different types of aircraft (Figure $4 \mathrm{C}$ ) and start the flight taking off from different airports worldwide or flying over the 
sector where the geosites are located. These virtual flights can be recorded using the Google Earth platform and can be played in different formats (avi., Mpeg.). In addition, they are compatible with a wide range of technologies (DVD players, smartphones, computers, tablets, etc.). From an educational point of view, this procedure allows participants to create a very familiar environment for young people, especially because of their similarity with videogames, increasing their interest in the route. A joystick can be connected to the application via a USB port to generate a feeling of greater reality, as if it were the cabin of a real plane (Figure $4 \mathrm{D}$ ).
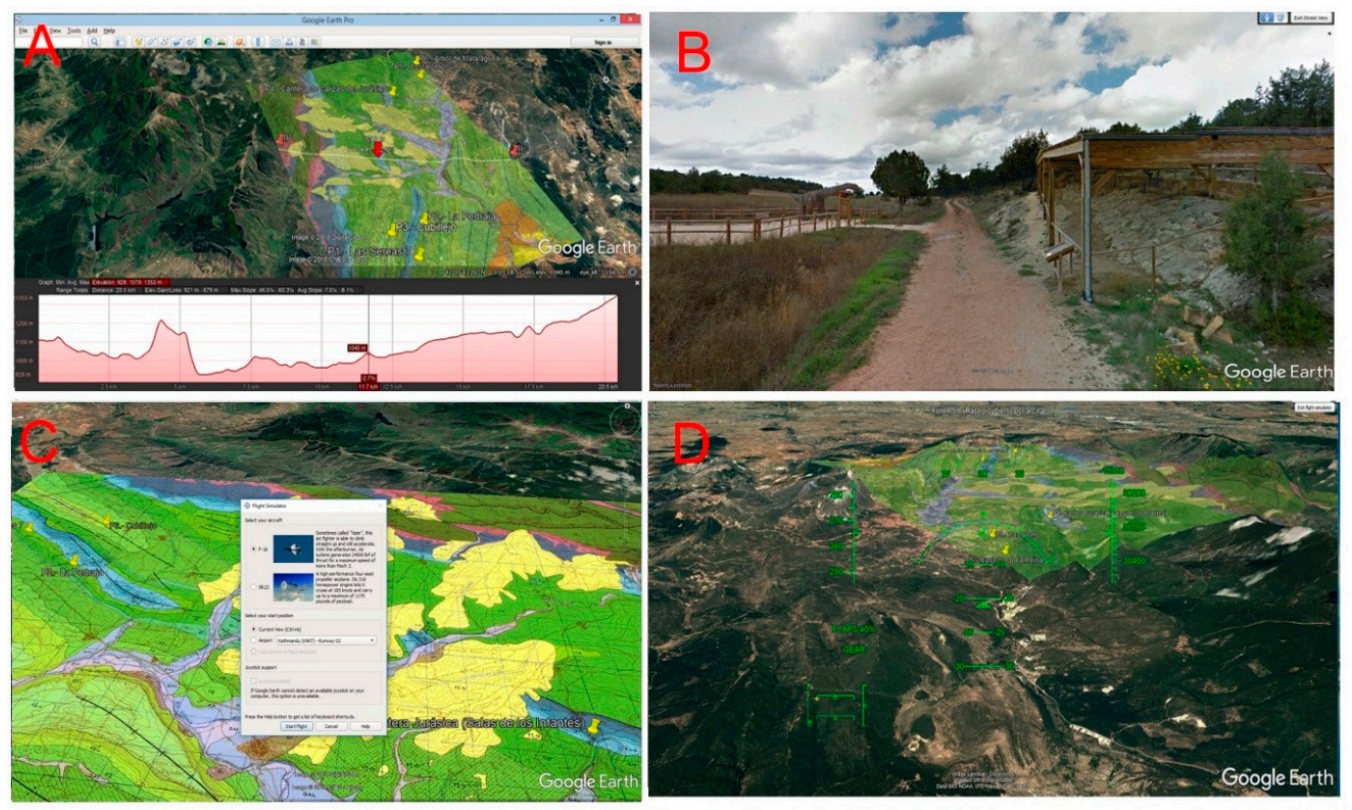

Figure 4. (A) Superimposition of the geological map on virtual globe and terrain profile with slopes and distances. (B) View capture on the device via Street View of the geosite 2 from the road. (C) Capture the virtual flight window where you can choose the type of aircraft in Google Earth. (D) Simulator capture with the flight screen commands beginning approaching the studio area and the geosites.

\subsection{Geoheritage and Georesources in Augmented Reality}

To generate descriptive and graphic material (images, diagrams and photographs), several field trips were made and a bibliography of the area and the subject was compiled. Information sheets and questionnaires for each geosite were designed. This information is grouped into cards that include basic information to interpret the geosite, its location, representative images and the evaluation of scientific, didactic and tourist-recreational interest.

In addition, a field guide has been prepared in a downloadable "pdf" format for some geosites with questions addressed to participants who, in order to answer them, must observe and interpret the forms, geological materials, structures and fossil footprints of each stop in the itinerary [28-31]. These documents include recommendations about the importance of the geological heritage, the considerations necessary for its preservation and a notice prohibiting of plunder or damage to the heritage resources.

A free "geoapp" application for Android, which only needs internet access for download and update, has also be been developed. In the application the route is introduced and a predetermined itinerary is proposed, so that it can be used as a teaching resource by the participants and the information of each geosite is included in English and Spanish, enabling and adapting the itinerary to participants from other countries or bilinguals. This application has been designed using comments which emphasize the importance of the preservation of the geological heritage, motivating the notification of any damage or theft to the competent authorities. It is a tool that can streamline the process of action and try to improve the preservation of heritage. 
The creation of the geoapp is done with a free application of the many available on the web and begins by giving the option to choose up to four types of wallpaper, in our case we chose the simplest to favour highlight text information and graphics. Next, an introduction in several languages is generated with a menu-like listing of the different geosites. Each one offers a link to a new window in which their characteristics are described; including diagrams, sheets, figures and photographs and some questionnaires where the participant can appreciate the degree of understanding reached. Finally, there is the option of being able to report incidents and share comments on social networks.

\section{Results and Discussion}

\subsection{Geological Itinerary}

Six geosites have been selected near the town of Salas de los Infantes, four easily accessible from the road and two requiring a short walk. These geosites are in a natural environment, relatively far from rural nuclei, which allows the visitor to discover an area of great beauty and multiple interests, featuring not only geological processes and structures but also natural phenomena with unique flora and fauna and cultural heritage, such as the Visigothic church of Quintanilla de las Viñas, or the nearby Monastery of Santo Domingo de Silos, as well as tourist activities such as museums, theme parks and so forth. The selected geosites are:

1. Site of Las Sereas 7 with dinosaur footprints. Located in the municipality of Quintanilla de las Viñas (Burgos) dated to an age of 145 m.y. corresponding to the Lower Cretaceous. The site constitutes the western part of the Las Sereas deposit, $5 \mathrm{~km}$ long and divided into several points (Figure 5A,B). The site has 60 very well preserved ichnites. Ichnites of Sauropods (herbivores), of Terópodos (carnivores) and of Ornitópodos (herbivores) are also present. This geosite is complemented by the great biodiversity of raptors (vultures) and plant species (junipers and olive trees), as well as being close to the Visigothic Church of Santa María (7th-8th century).

2. La Pedraja site with dinosaur footprints. Located in Mambrillas de Lara, on a small slope at the foot of the road. It represents the eastern edge of the Sereas area. This site presents dinosaur ichnites Sauropods, Theropods and Ornithopods, discovered in 1982 and declared an Asset of Cultural Interest for its paleontological interest (Figure 5C,D). The site is composed of 2 rocky levels with a total of 23 ichnites or fossil footprints of dinosaurs, where most of the tracks are isolated since there is only one trace formed by 3 ichnites. A fiberglass reconstruction of the large dinosaur that would have stepped there is also presented (Figure 5E). The reconstruction measures $12.5 \mathrm{~m}$ long and almost 4 high.

3. Cubillejo. Located in the municipality of Quintanilla de las Viñas, it has an age of 93-100 m.y. of the Upper Cretaceous (Figure 5F). The stop is next to a small town called Cubillejo, it constitutes folded materials in a NW-SE direction with an alternation of limestones and marls from the Upper Cretaceous. These limestones have advanced stages of dissolution by rainwater generating karren-type landscapes. They complement this parade of Palaeolithic remains.

4. Jurassic limestone quarry with marine invertebrates. Limestone aged 166-168 m.y. corresponding to the Upper Jurassic and constitutes thrusts generated in the Alpine relief. They are sandy limestones, marls and marine dolomites and represent a marine environment with little depth. There are marine fossils (Figure 5G) that have been little transported since they present low fragmentation and abrasion. The most abundant are Pectinids, remnants of Equinids, Brachiopods, Ammonites, Belemnitids and Crinoids.

5. Costalomo, a reservoir featuring dinosaur ichnites that are preserved in an unusual manner. Located in the municipality of Salas de los Infantes with an age of 132-139 m.y. corresponding to the lower Cretaceous (Figure 5H). This site is considered unique in the world due to the peculiarities of its conservation as a positive relief on the strata of sands and conglomerates (Facies Utrillas). It was declared an Asset of Cultural Interest in 2005. The dinosaur footprints are presented as reliefs that protrude from the sandstone layer and not as cavities as is typical of dinosaur footprints [27]. 
6. Matalaguna fossil tree. This site is located in the municipality of Castrillo de la Reina with an age of 132-139 m.y., of the Lower Cretaceous. This deposit represents one of largest examples of a fossilized tree (Figure 5I). A fossil trunk of $16.5 \mathrm{~m}$ is well preserved inside an enclosure built in 2010 to protect it from erosion. The vegetal structure has been silicified and manages to preserve the details of the bark. It was an evergreen tree of the proto-podocarpaceae family, corresponding to the current austral pine, which lived in this marshy area.

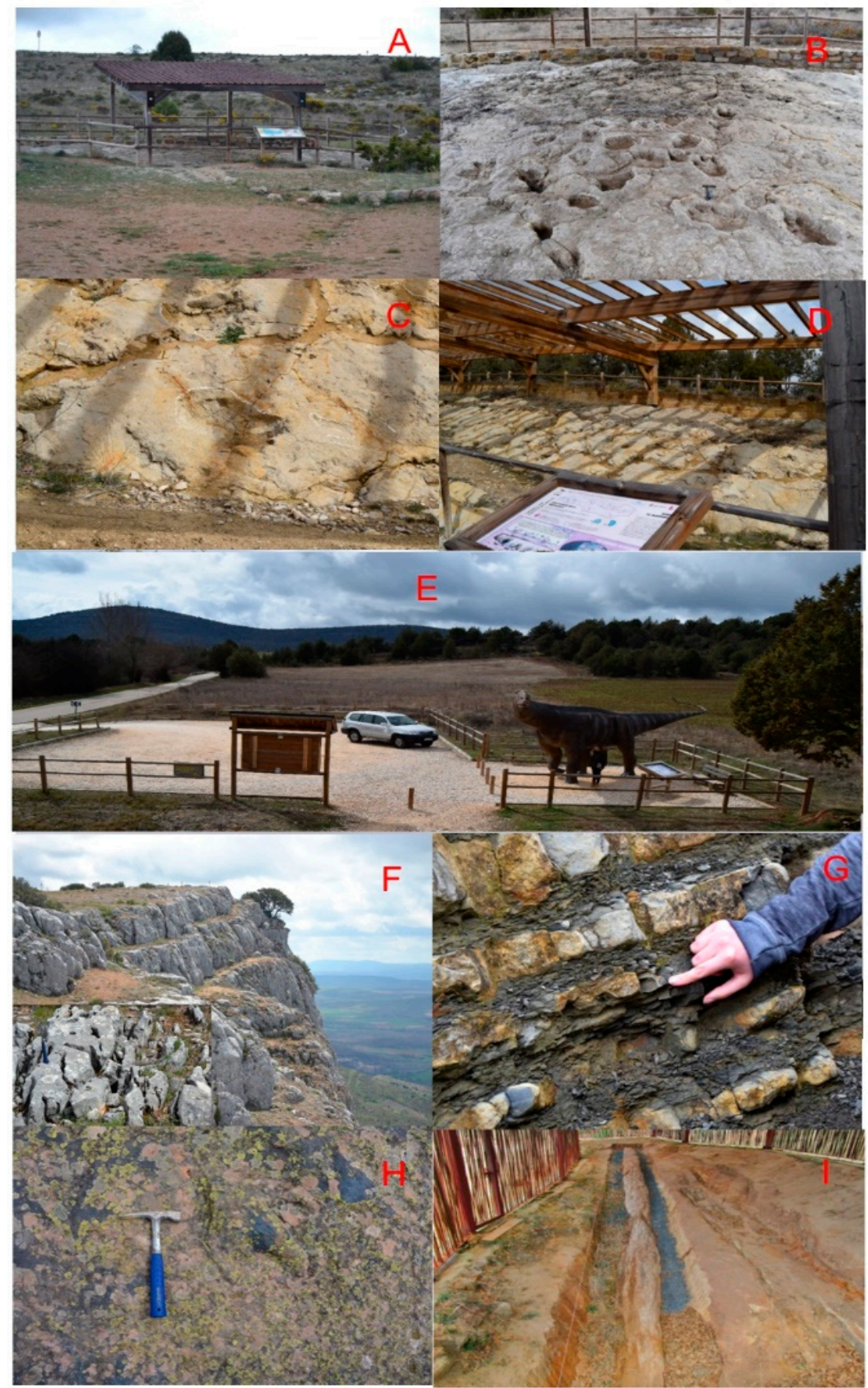

Figure 5. (A) cover under which are the tracks of the dinosaurs. (B) Detail of the size of dinosaur footprints in geosite 1. (C) Dinosaur footprint marks in geosite 2, with an informative panel (D) and idealized prototype at real size (E). (F) Outcrop of limestones with dissolution process and karren generation. (G) Outcrop in which fragments of pectinids and sea urchins are observed. (H) Sauro footprints with relief on the surface of the rock stratum. (I) Remains of the petrified fossil tree. 
The results obtained in the global assessment of the 18 parameters are observed in Table 1 and their assessment by scientific, educational, or tourist-cultural interest is included in Table 2 . The results of the evaluation are shown in Tables 3 and 4.

Table 3. Geosite values.

\begin{tabular}{lcccccc}
\hline Geosites & $\mathbf{1}$ & $\mathbf{2}$ & $\mathbf{3}$ & $\mathbf{4}$ & $\mathbf{5}$ & $\mathbf{6}$ \\
\hline Representativeness & 2 & 2 & 1 & 2 & 4 & 2 \\
Character type locality & 2 & 1 & 1 & 1 & 4 & 1 \\
Degree of scientific knowledge of the location & 2 & 4 & 1 & 2 & 4 & 0 \\
State of conservation & 2 & 4 & 4 & 1 & 4 & 4 \\
Viewing conditions & 4 & 4 & 4 & 4 & 2 & 4 \\
Rarity & 2 & 1 & 1 & 2 & 4 & 4 \\
Geological diversity & 0 & 2 & 2 & 2 & 2 & 1 \\
Learning objectives/educational use & 4 & 2 & 1 & 2 & 2 & 2 \\
Logistics infrastructure & 4 & 2 & 1 & 4 & 1 & 4 \\
Population density & 1 & 1 & 1 & 1 & 1 & 1 \\
Accessibility & 2 & 4 & 0 & 4 & 1 & 1 \\
Intrinsic fragility (geosite size) & 1 & 2 & 4 & 1 & 1 & 1 \\
Association with elements natural and/or cultural & 2 & 2 & 2 & 1 & 0 & 1 \\
Beauty or spectacularity & 2 & 2 & 1 & 2 & 2 & 2 \\
Informative content/use & 4 & 2 & 1 & 2 & 4 & 2 \\
Potential for tourism/recreation activities & 2 & 2 & 0 & 2 & 2 & 1 \\
Proximity to recreational areas & 1 & 2 & 0 & 2 & 0 & 1 \\
Socioeconomic environment & 1 & 1 & 1 & 1 & 1 & 1 \\
Total & $\mathbf{3 8}$ & $\mathbf{3 8}$ & $\mathbf{2 6}$ & $\mathbf{2 8}$ & $\mathbf{2 9}$ & $\mathbf{3 0}$ \\
\hline
\end{tabular}

Table 4. Scientific, didactic and tourist-cultural interest.

\begin{tabular}{ccccccc}
\hline Geosites & $\mathbf{1}$ & $\mathbf{2}$ & $\mathbf{3}$ & $\mathbf{4}$ & $\mathbf{5}$ & $\mathbf{6}$ \\
\hline Scientific interest & 215 & 225 & 170 & 110 & 210 & 190 \\
Didactic interest & 250 & 250 & 130 & 250 & 165 & 210 \\
Tourist-cultural interest & 205 & 200 & 145 & 145 & 125 & 135 \\
Total & $\mathbf{6 7 0}$ & $\mathbf{6 7 5}$ & $\mathbf{4 4 5}$ & $\mathbf{5 0 5}$ & $\mathbf{5 0 0}$ & $\mathbf{5 3 5}$ \\
\hline
\end{tabular}

The geosites 2 (La Pedraja) and 1 (Las Sereas 7) achieve the highest valuation, with 675 and 670 points. Their scientific, educational and tourist-cultural values are very similar, since they are part of the same facies, separated by several $\mathrm{km}$ and in both have structures to protect them, as well as informative panels for the general public on the meaning of the dinosaur ichnite that characterize the geosites. Geosite 3 (Cubillejo) is the one with the lowest value of 445 . Despite its high scientific interest, it presents access difficulties, which limits its educational and touristic use. Geosite 6, with a total of 535 points, is also remarkable, since the presence of a large fallen fossil tree, with an exceptional state of conservation and ease of access, provides a high educational value (it has been visited by university students for years) and touristic (there is good access to the geosite, which also has a protective structure).

\subsection{Georesources Implemented in the Augmented Reality}

\section{D Virtual Itinerary with Google Earth}

Using Google Earth, the geosites, georeferenced with representative images and descriptive information and assessment of the geological heritage and their scientific, didactic and tourist-recreational interest, are incorporated into the itinerary (Figure 6A). A SW-NE geological section is selected that analyses the arrangement of the geological materials of the first three geosites (left of the geologic profile) and of the last three (right geologic profile). This allows the participants to visualize the geological context, the events that have taken place in this sector (folds and faults) and the 
relationships between the places of interest (Figure 6B,C). In addition, from the archives of the stops, the itinerary can be modified in real time. A field guide was prepared for the participants in "pdf" format with activities and questionnaires on singular aspects of the geosites, increasing the interactivity between what is actually seen in the geosite and the previous knowledge of each person, allowing participants to advance their knowledge with images, interpretations and to explore issues actively.

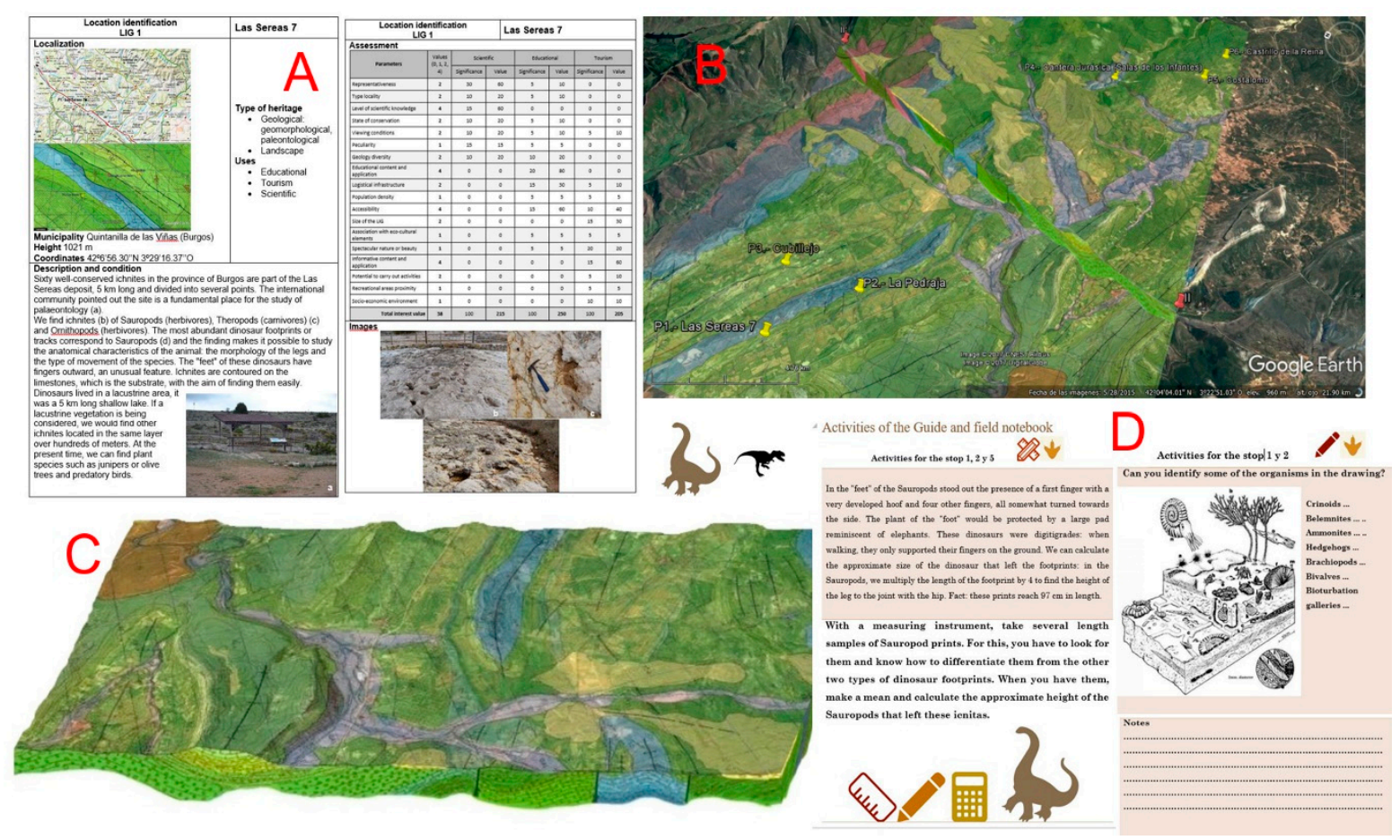

Figure 6. (A) Descriptive sheets for each of the geosites analysed. (B) Geological cartography with transparency on orthophoto incorporating a geo-referenced geological cut. (C) 3D diagram block in which the in-depth arrangement of the geological materials is observed where the fossil footprints of the itinerary are located. (D) Field guide for participants "pdf" with activities and questionnaires on singular aspects of the geosites.

A 3D virtual flight has been realized that can be implemented in mobile devices generating geomatic applications that create a geospatial vision that interacts with the georeferenced geosites on the 3D virtual globe of Google Earth and visualizes the geosites in the terrain (Figure 7) and can analyse, using augmented reality, the interpretations, evaluations and so forth and improve the understanding of the geoheritage. In addition, the GPS integrated in these devices has allowed us to interact with Google Maps and observe the location of each geosite with Street View, generate the elevation profile and the difficulty of the route: slopes, times, distances and so forth, (Figure 4A) and trace the georeferenced route between different geosites (Figure 3C). The virtual flight generated with the Google Earth platform presents "on the fly" descriptions and photographs, so that the participant can search for said information that they see in the already interpreted mobile device (augmented reality) and the view of the terrain in real time. The virtual flight has been recorded as a "Kml" file of Google Earth, which will allow any user to reproduce it. Videos have been made (see Supplementary Materials), which show in detail the itinerary, approaching and moving away through the virtual globe. They have been transformed into "avi," "mp4," or "mpeg" format and can be incorporated and played in any media player (TV, iPod, etc.). 

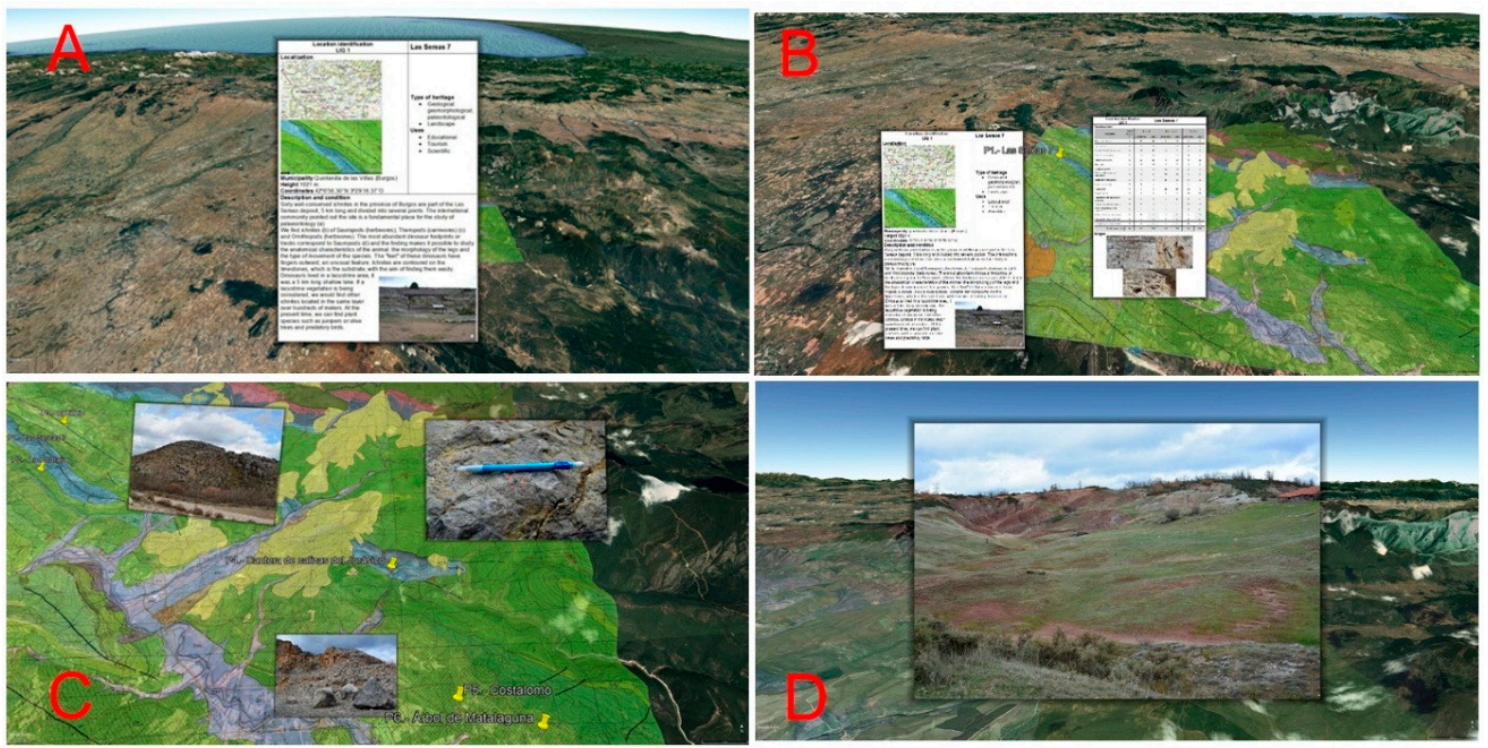

Figure 7. (A) Capture of the descriptive sheet and interpretative schemes of geosite 2 . (B,C) Georeferenced photographs on the 3D geological mapping on the virtual globe. (D) Detail of the interaction of a photograph on the Google Earth application.

In addition, to facilitate the use of these materials and enhance the geological heritage of the area, a geoapp has been designed for the Android system, downloadable on any mobile device with the "Play Store" application, which displays information organized by geosites and enables the user to execute didactic activities and consult or share information in a comments section. To facilitate the download, a QR code has been included. This geoapp presents a menu (Figure 8) with a series of sections that inform about the route in general, how to carry it out in the proposed order, a temporary outline of the stops, the six stops explained with images that can be enlarged and a "chat" to leave comments for other future users. This section of comments would be used to share images or additional information from visitors, as well as warn of possible deterioration in the conservation of heritage. This chat will encourage users to inform local authorities of issues so that the appropriate measures are taken. Activities in the application are grouped according to their subject. In addition, the application offers the option to share it with your contacts through any application that is installed on the device. The Geoapp is available in Spanish and English, with the purpose of being used by bilingual tourists and any non-Spanish-speaking public. The configuration of the general language of the application depends on the personal configuration of the device, being able to be configured in any desired language. 


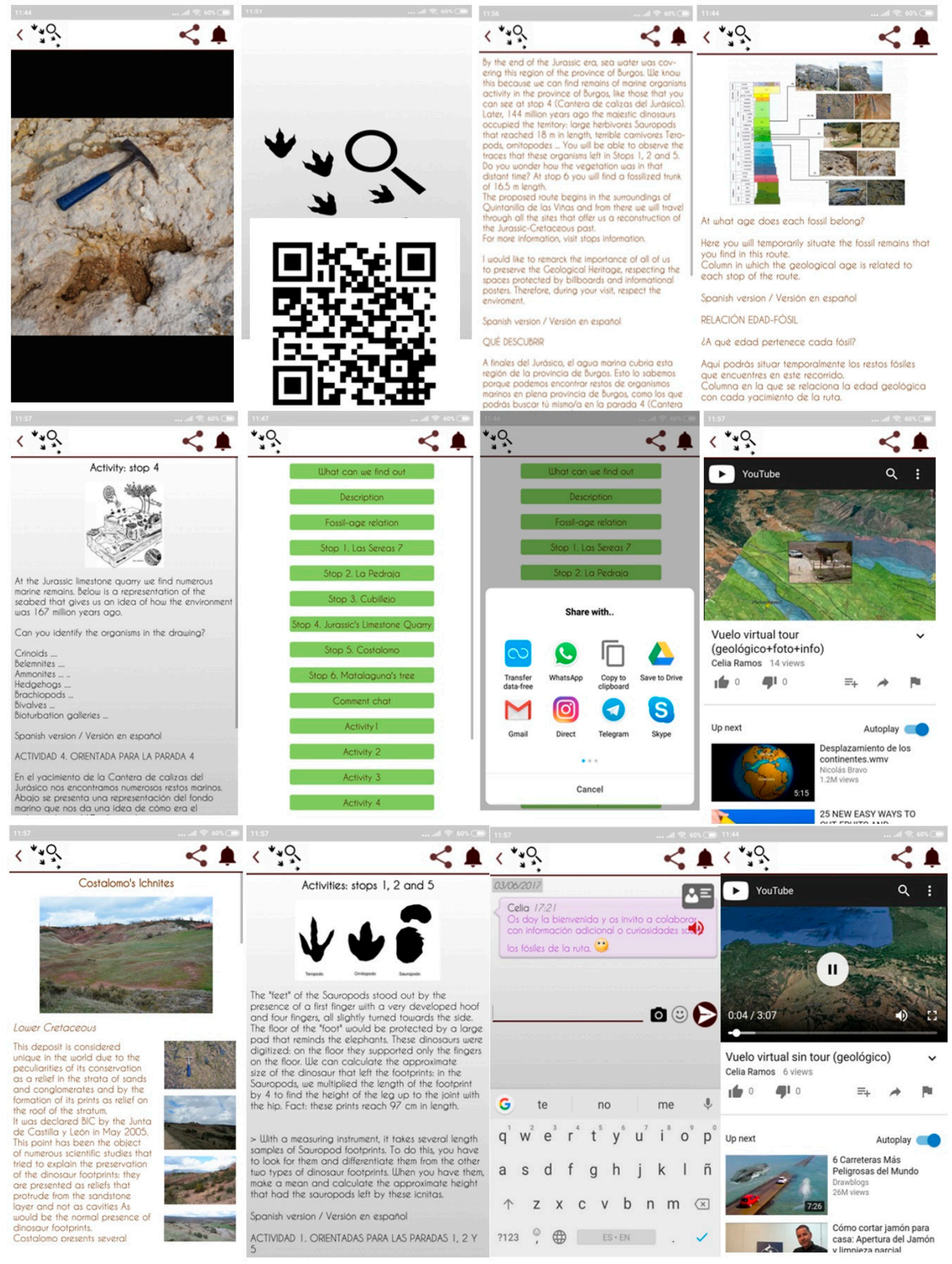

Figure 8. Geoapp "Burgos fossil route" for Android, where you can see the main menu with the different sections, QR code for download, the description and information of the geosites of the route, activities and comments chat.

The validation with statistical data of these results in education is being implemented in students of different educational stages (degree and master). At the moment, the procedure applied with 3D virtual routes is satisfactory because of the ease of use and obtaining additional digital documentation 
about the places that are being visited. The students' response is favourable since they have gone from the traditional excursion with a paper field guide to being able to interact with one of the most familiar devices for them (smartphone), the teaching-learning procedure being more dynamic. The most common opinion of the participants is that it allows an easy geolocalization of the different geosites about the geological distribution in the territory and it facilitates discovering in the outcrops "in situ," elements of the geological heritage from the downloadable virtual interpretative schemes.

\section{Conclusions}

Advances in geomatic resources and the implementation of augmented reality in the improvement and understanding of natural environments from mobile devices allow a considerable improvement in the degree of acquisition of teaching concepts through teaching-learning processes carried out in the medium is natural, especially in matters related to earth sciences. This paper presents a methodology to develop intelligent itineraries in natural areas that values the importance of geological heritage and provides an educational resource with which the concepts are integrated into a geological context.

The use of applications and programs such as those presented help participants to spatially visualize geological maps (geomorphology and stratigraphy) and facilitate the integration of new technologies into society and into certain tourist-teaching environments. These resources stimulate creativity and the rapid acquisition of a collaborative character while promoting the autonomous learning of the students. This methodology provides a practical perspective to the curriculum of secondary education, transmitting information in a simple way to students in a digital format with which they are familiar (videos, images, virtual reality).

The itinerary, comprising six geosites in the area of Salas de los Infantes (Burgos), containing dinosaur images, fossil trees, fossil marine fauna and karstic landscapes of lapiaz identifies and evaluates scientific, educational and tourist-recreational interest, ranging from 445 and 675. In addition, those values are implemented, with the use of Google Earth (geo-referenced and highly interoperable routes), in virtual 3D flights, didactic material and a mobile application. Thanks to the fact that this itinerary is georeferenced with accessible and free software, it can serve as a resource. The work includes a temporary schedule and material to make the itinerary simple and practical.

The geomatics resources of augmented reality should be made available for the development of sustainable geotourism, particularly in vulnerable sectors that require more effort their conservation, and, furthermore, such resources should be considered beneficial for the biological and sociocultural environment of the area.

Supplementary Materials: Placemarks in KML, VirtualFlight video in $\mathrm{mp} 4$ format. The following are available online at http:/ / www.mdpi.com/2071-1050/10/12/4616/s1.

Author Contributions: Conceptualization, A.M.-G. and J.Á.G.-D.; methodology, C.R.; software, A.M.-G.; validation, C.R., J.Á.G.-D. and J.C.G.; formal analysis, C.R.; investigation, C.R.; resources, A.M.-G.; data curation, C.R.; writing-original draft preparation, A.M.-G.; writing—review and editing, J.C.G.; visualization, C.R.; supervision, J.Á.G.-D.; project administration, A.M.-G.; funding acquisition, A.M.-G.

Funding: This research was funded by projects: Junta Castilla y León SA044G18 and USAL (2017) 46AC0; and projects from the Ministry of Economy and Competitiveness CGL2015-67169-P and CGL2015-69919-R.

Conflicts of Interest: The authors declare no conflict of interest.

\section{References}

1. Gallego, E.; García-Cortés, A. Patrimonio geológico y áreas naturales protegidas. Geogaceta 1996, 19, $202-206$.

2. Carcavilla Urqauí, L.; López Martínez, J.; Durán Valsero, J.J. (Eds.) Patrimonio Geológico y Geodiversidad: Investigación, Conservación, Gestión y Relación Con Los Espacios Naturales Protegidos; Cuadernos del Museo Geominero No. 7; Instituto Geológico y Minero de España: Madrid, Spain, 2017; Volume 7, 360p.

3. Gray, M. Geodiversity: Valuing and Conserving a Biotic Nature; Wiley: Hoboken, NJ, USA, 2003; 434p.

4. Parks, K.E.; Mulligan, M. On the relationship between a resources based measure of geodiversity and broad scale biodiversity patterns. Biodivers. Conserv. 2010, 19, 2751-2766. [CrossRef] 
5. Barretino, D.; Wimbledon, W.A.P.; Gallego, E. Patrimonio Geológico: Conservación y Gestión; IGME: Madrid, Spain, 2000; 227p.

6. Martínez Graña, A.M.; Goy Goy, J.L.; Zazo Cardeña, C. Natural Heritage mapping of the Las Batuecas-Sierra de Francia and Quilamas Nature Parks (SW Salamanca, Spain). J. Maps 2011, 7, 600-613. [CrossRef]

7. Zouros, N.C. Geomorphosite assessment and management in protected areas of Greece Case study of the Lesvos Island coastal geomorphosites. Geogr. Helv. 2007, 62, 169-180. [CrossRef]

8. Bruschi, V.M.; Cendrero, A. Geosite evaluation; can we measure intangible values? II Quaternario Ital. J. Quarternary Sci. 2005, 18, 293-306.

9. Nicu, I.C. Tracking natural and anthropic risks from historical maps as a tool for cultural heritage assessment: A case study. Environ. Earth Sci. 2017, 76, 330. [CrossRef]

10. Weng, Y.-H.; Sun, F.-S.; Grigsby, J.D. Geotools: An Android phone application in geology. Comput. Geosci. 2012, 44, 24-30. [CrossRef]

11. Bailey, J.E.; Chen, A. The role of virtual globes in geoscience. Comput. Geosci. 2011, 37, 1-2. [CrossRef]

12. Blenkinsop, T.G. Visualizing structural geology: From Excell to Google Earth. Comput. Geosci. 2012, 45, 52-56. [CrossRef]

13. De Paor, D.; Whitmeyer, S.J. Geological and geophysical modelling on virtual globes using KML, COLLADA and Javascript. Comput. Geosci. 2011, 37, 100-110. [CrossRef]

14. Karabinos, P. Adding structures to 3-D geologic maps. In Proceedings of the Geological Society of America Annual Meeting, Denver, CO, USA, 31 October-3 November 2010; Abstracts with Programs-Geological Society of America. Volume 42, p. 421.

15. Martínez-Graña, A.M.; Serrano, L.; Gonzál ez-Delgado, J.A.; Dabrio, C.J.; Legoinha, P. Digital Geotourism: Tools and resources for sustainability and tourism management. Georoute "Route of the fossil footprints" (Monsagro, Salamanca, Spain). Int. J. Dig. Earth 2017, 10, 121-138. [CrossRef]

16. García-Cortés, A.; Carcavilla, L.; Díaz-Martínez, E.; Vegas, J. Documento metodológico para la elaboración del inventario español de Lugares de Interés Geológico (IELIG). Instituto Geológico y Minero de España 2014, $12,61$.

17. Brilha, J. Inventory and quantitative assessment of geosites and geodiversity sites: A review. Geoheritage 2016, 8, 119-134. [CrossRef]

18. Reynard, E.; Perret1, A.; Bussard, J.; Grangier, L.; Martin, S. Integrated Approach for the Inventory and Management of Geomorphological Heritage at the Regional Scale. Geoheritage 2016, 8, 43-60. [CrossRef]

19. Corbí, H.; Fierro, I.; Aberasturi, A.; Ferris, E.J.S. Potential Use of a Significant Scientific Geosite: The Messinian Coral Reef of Santa Pola (SE Spain). Geoheritage 2018, 10, 427-441. [CrossRef]

20. González-Delgado, J.A.; Martínez-Graña, A.M.; Civis, J.; Sierro, F.J.; Goy, J.L.; Dabrio, C.J.; Ruiz, F.; González-Regalado, M.L.; Abad, M. Virtual 3D tour of the Neogene palaeontological heritage of Huelva (Guadalquivir Basin, Spain). Environ. Earth Sci. 2015, 73, 4609-4618. [CrossRef]

21. Martínez-Graña, A.M.; Legoinha, P.; González-Delgado, J.A.; Dabrio, C.J.; Pais, J.; Goy, J.L.; Zazo, C.; Civis, J.; Armenteros, I.; Alonso-Gavilán, G.; et al. Augmented Reality in a hiking tour on the Miocene geoheritage of central Algarve cliffs (Portugal). Geoheritage 2017, 9, 121-131. [CrossRef]

22. Martínez-Graña, A.M.; Bajo, I.; González-Delgado, J.A.; Cárdenas-Carretero, J.; Abad, M.; Legoinha, P. Virtual geo-resources applied to the palaeontological heritage in Sevilla (Guadalquivir Neogene basin, Spain). Geoheritage 2018, 10, 473-482. [CrossRef]

23. Martínez-Graña, A.M.; González-Delgado, J.A.; Pallarés, S.; Goy, J.L.; Civis, J. 3D Virtual Itinerary for Education Using Google Earth as a Tool for the Recovery of the Geological Heritage of Natural Areas: Application in the "Las Batuecas Valley" Nature Park (Salamanca, Spain). Sustainability 2014, 6, 8567-8591. [CrossRef]

24. Benito-Calvo, A.; Pérez-González, A. Geomorphology of the Sierra de Atapuerca and the Middle Arlanzón Valley (Burgos, Spain). J. Maps 2014, 11, 535-544. [CrossRef]

25. Álvarez-Vázquez, M.Á.; De Uña-Álvarez, E. Inventory and Assessment of Fluvial Potholes to Promote Geoheritage Sustainability (Miño River, NW Spain). Geoheritage 2017, 9, 549-560. [CrossRef]

26. Suzuki, D.; Takagi, H. Evaluation of Geosite for Sustainable Planning and Management in Geotourism. Geoheritage 2018, 10, 123-135. [CrossRef]

27. Štrba, L'.; Kršák, B.; Sidor, C. Some Comments to Geosite Assessment, Visitors, and Geotourism Sustainability. Sustainability 2018, 10, 2589. [CrossRef] 
28. García Cortés y Carcavilla. 2018. Available online: http://www.igme.es/patrimonio/descargas/ METODOLOGIA\%20IELIG\%20V16\%20actualizaci\%C3\%B3n\%202018.pdf (accessed on 3 December 2018).

29. Kiili, K. Digital game-based learning: Towards an experiential gaming model. Internet High Educ. 2005, 8 , 13-24. [CrossRef]

30. Zingaro, D.; Porter, R. A model of consumer web navigational behavior: Conceptual development and application. J. Bus. Res. 2005, 58, 1019-1029.

31. Huerta, P.; Torcida, F.; Farlow, J.O.; Montero, D. Exceptional preservation processes of 3D dinosaur footprin casts in Costalomo (Lower Cretaceous, Cameros Basin, Spain). Terra Nova 2012, 24, 136-141. [CrossRef]

2018 by the authors. Licensee MDPI, Basel, Switzerland. This article is an open access article distributed under the terms and conditions of the Creative Commons Attribution (CC BY) license (http://creativecommons.org/licenses/by/4.0/). 